\begin{tabular}{|r|}
\hline ANGIES \\
NEW PERSPECTIUE5 \\
ANGLOPHINE WTRLD \\
\hline
\end{tabular}

\title{
Angles
}

New Perspectives on the Anglophone World

$8 \mid 2019$

Neoliberalism in the Anglophone World

\section{How To "Talk Left and Walk Right" in South Africa: Access to Medicines in the Neoliberal Era}

An insight into the public market of antiretroviral treatments in South Africa

\section{Charlotte Pelletan}

\section{(2) OpenEdition}

Journals

Electronic version

URL: https://journals.openedition.org/angles/613

DOI: 10.4000 /angles.613

ISSN: 2274-2042

Publisher

Société des Anglicistes de l'Enseignement Supérieur

\section{Electronic reference}

Charlotte Pelletan, "How To "Talk Left and Walk Right" in South Africa: Access to Medicines in the Neoliberal Era", Angles [Online], 8 | 2019, Online since 01 April 2019, connection on 08 June 2022. URL: http://journals.openedition.org/angles/613 ; DOl: https://doi.org/10.4000/angles.613

This text was automatically generated on 8 June 2022.

Angles est mise à disposition selon les termes de la Licence Creative Commons Attribution 4.0 International. 


\title{
How To "Talk Left and Walk Right" in South Africa: Access to Medicines in the Neoliberal Era
}

An insight into the public market of antiretroviral treatments in South Africa

Charlotte Pelletan

\section{Introduction}

\author{
"I am not using strong words; I am using \\ appropriate words. This is genocide". \\ Health Minister Aaron Motsoaledi (De Wet 2014)
}

\section{When the Minister of Health talks left...}

1 In 1997, while the AIDS epidemic was spreading, the South African government explored changes to its regulation of patents in the Medicines Act and its National Drug Policy. It triggered a world-famous law case pitting the South African state against a coalition of pharmaceutical companies: the Medicines Act case, which concluded in 2001, also known as the Pretoria trial.

2 Since the Pretoria trial, debates on access to antiretroviral treatments (ARVs) have been polarized between activists - supported by the Minister of Health - who urge to apply exceptions (also called flexibility) to the Agreement on Trade-Related Aspects of Intellectual Property Rights (TRIPS) and the global pharmaceutical industry, which is keen to protect its interests. As a result, the HIV/AIDS epidemic has been highly politicized since the end of Apartheid, once through denialism and then with the massive roll-out of antiretroviral treatments after the Pretoria trial.

3 Since then, universal access to antiretroviral treatments has been a pillar of African National Congress (ANC) policy. After announcing constitutional equality, with section 
27 of the constitution introducing access to health as a fundamental principle, the ANC government has tried to ground its legitimacy in the achievement of these socioeconomic rights, namely through equal access to treatments (Hodgson 2015). Health Minister Motsoaledi's governance has promoted a "welfarist" vision of the state, framed by the principle of universal socio-economic rights. One of his major proposals is the implementation of a National Health Insurance in South Africa (NHI): "NHI is a reflection of the kind of society we wish to live in - a society that will be based in values of justice, fairness and social solidarity" (Motsoaledi 2014). Health policies indeed seem to be used by Motsoaledi as a "specific legitimization resource for governments" (Fassin 1998). According to an industry manager, "every ANC president has left a legacy: Mandela has brought reconciliation, Mbeki the African Renaissance and Zuma will bring healthcare." (Motsoaledi 2015b) As a matter of fact, AIDS response has been at the core of a broad reform project supposed to lead to the implementation of a National Health Insurance (NHI): "We know by now that there are four (4) highways along which South Africans are marching to their graves (...)." Among them is "a huge burden of HIV and AIDS and TB - this is the biggest highway of them all with many many lanes" (Motsoaledi 2016).

\section{... And walks right?}

4 Aaron Motsoaledi's mandate has been characterized by hyperactivity. His reform project was merely for the show, as demonstrated by the shilly-shallying around the implementation of NHI or his crusade against patents. Indeed, in spite of its strong rhetoric, the Department of Health has never resorted to TRIPS flexibility to reduce the price of medicines ${ }^{1}$, nor has it developed alternatives to dependence on foreign pharmaceutical supplies. No long-term investment has been made to secure the supply of antiretroviral treatments in South Africa (Kudlinski 2013) and a strategy based on attracting direct foreign investment has been favoured. Consequently, in spite of WHO recommendations, local industry has developed little manufacturing capacity and relies almost exclusively on imported Active Pharmaceutical Ingredients (Kudlinski 2013). This situation leads to the Department of Health (DoH)'s strong dependence on multinational pharmaceutical businesses. Far from following a developmental approach to health systems, the Health Minister has designed an access policy based on a low-cost, rationalized supply, contrary to the Department of Trade and Industry (DTI)'s industrialization strategy.

5 The aim of this article is to explore the contemporary dynamics of the public supply of antiretroviral (ARV) treatments in South Africa. I will show that the development of ARV treatments has been paradoxically based on the development of the relationships between the state and multinational business. More precisely, the DoH has deepened its relations with the latter by establishing the public market as a strategic hub in South Africa. This way, the South African government has developed a strong influence on the market of medicines within the territory. This article suggests that, in a resourceconstrained context which questions the country's capacities for traditional welfarism, the DoH strengthens its reach by vesting market rules. By vesting, we refer to "institutional work directed toward the creation of rule structures that confer property rights (Roy, 1981; Russo, 2001). Vesting occurs when government authority is used to reallocate property rights [...]." (Lawrence and Suddaby 2006). 


\section{Methodology}

6 There is a wide body of research on the impact of neoliberalism on access to healthcare and medicines (for instance: McGregor 2001, Chapman 2014). Most of it deals with structural adjustment programmes in Southern countries and more recently on the effects of the financial crises (Legido-Quigley et al. 2016). The common narrative states that "the neoliberal offensive has had a major disruptive effect on social cohesion, as well as on people's lives and morale, especially the most vulnerable" (Karamessini 2012: 176). Moreover, neoliberalism would entail the retreat of the state from its social functions, as the "important element of neoliberalism is the retrenchment of the welfare dimension of the state, which is seen as an impediment to the optimal functioning of the markets" (Mladenov 2015: 446). Based on the assumption that the decrease of public budget expenditure and predatory austerity result in the collapse of health policies, these studies overlook the concrete strategies implemented to circumvent these constraints.

7 This article criticizes such understandings of the workings of neoliberalism. By contrast, it is based on the methodological assumption that neoliberalism should not be studied as the retreat of the state but as a political production which carries specific social relationships (Boyer 2015). Resorting to heterodox economics and sociology helps escape the black-and-white distinction between strong (welfare) and weak (neoliberal) states developed for instance by varieties-of-capitalism literature (Hall and Soskice 2001), and sheds a light on a fundamental paradox: it takes a strong state to engineer its own downsizing. Neoliberal states do not disappear but turn into invisible market managers and keep steering market forces:

It is too often forgotten that neo-liberalism seeks not so much the 'retreat' of the state, and an expansion of the spaces of capital accumulation, as the transformation of state action by making the state itself a sphere governed by rules of competition and subject to efficiency constraints similar to those experienced by private enterprises. [...] More profoundly, it signifies a transformation of the 'format' and role of the state, which is now perceived as an enterprise in the service of enterprises. (Dardot and Laval 2013: 216, 228)

As Peck puts it, neoliberalization processes imply the successive "roll back and roll-out of state functions" (Peck 2013: 447). What it means is that the state does not disappear but rather restructures its links with all policy stakeholders: the state as a political project "is being replaced, not by fresh air and free markets, but by a reorganized state apparatus" (Peck 2013: 447) which conforms society to market forces. What is at stake in the analysis of neoliberal states is also a methodological challenge which entails that we look at "how neoliberalism is specified in a variegated landscape of institutional, economic and political forms" (Peck 2013). The historical, sociological and political modalities of its reorganization are at the core of the notion of neoliberalism, as Jessop suggests that we "put neoliberalism in its time and place" (Jessop 2013).

Such an approach of social and health policies in neoliberal contexts has been offered by Collier (2011) and Ferguson (2015). The former looked at the ways in which neoliberalism reshaped social welfarism by investigating post-Soviet Russia; the latter focused on Sub-Saharan countries. James Ferguson explains that, in a neoliberal context, the governments of those countries increasingly rolled out "extensive social welfare programs targeting the poor" (Ferguson 2015: 1). This way, he takes the 
opposing view of the narratives which expatiate upon the fact that neoliberalism is systematically detrimental to welfarism and interventionism (Evans 2008).

Consequently, this article shows that access policies in South Africa are not based so much on the reform of intellectual property law but on the gradual transformation of the market according to health priorities and negotiations with industry. I shall resort to the theory of regulation elaborated by Robert Boyer. This research looks at the arenas of negotiation within the public market of medicines and shows that policies are horizontally negotiated, between state and non-state actors (Nay and Smith 2002). Such an approach is inspired by the sociology of regulation, which de-constructs institutions through the analysis of concrete interactions.

11 Countries' trajectories on access issues have been broadly studied for India (Correa 2013) and Brazil (Sweet and Keshab 2013). The public market of antiretroviral treatments is a core issue for access to medicines, all the more since it is the most attractive market segment for multinational pharmaceutical companies in South Africa. DoH control over the selection of antiretroviral treatments gives it power over multinational industrial companies. This article is especially based on the analysis of tendering processes, with an extensive use of interviews with state department civil servants and pharmaceutical companies managers. The interviews mainly took place in Johannesburg and Pretoria in 2015.

This article falls into three parts: the first provides a background on the policy forum around access to medicines that has developed both at the international and national levels. The second expatiates upon the case of South Africa, showing how the pharmaceutical market has gradually been vested by health institutions. The final part explains how the Department of Health has become the go-to institutional partner for industry stakeholders.

\section{The rising narrative of access to health in the global pharmaceutical sector}

\section{Conflicting agendas: the Agreement on Trade-Related Aspects of Intellectual Property Rights (TRIPS) versus the development of a right to health}

13 Access to medicines has been put on the international agenda in a context of globalization of trade rules and commodification of knowledge. The dissemination of patents in Southern countries has led to a conflictual policy forum. ${ }^{2}$ In South Africa, the political will to align with international trade regulations has been at odds with the necessity to respond to the huge burden of HIV/AIDS epidemic after a decade of denialism. The notion of access to medicines emerged as a reaction to trade globalization and more especially to the Agreement on Trade-Related Aspects of Intellectual Property Rights (TRIPS). At the same time, South Africa came to terms with Apartheid with a contradictory mandate: ensuring the development of constitutional and socioeconomic rights by promoting a developmental state while entering the global market.

14 Since then, constitutional equality has been the first achievement of ANC governments in the Post-Apartheid era (Section 27: Right to Health), but the achievement of socio- 
economic rights has been continuously delayed by the global orthodox agenda. "The ANC government has been more interested in confirming its presence on the international scene and in conquering the international market than in ensuring socioeconomic rights" according to Professor V from the University of Kwazulu Natal (Professor V 2015). The ANC's desire to integrate South Africa into international trade regulations after the end of the Apartheid embargo led to a quick U-turn in the government's strategy. The adoption of the Growth Employment and Redistribution (GEAR) macroeconomic strategy in 1996 has been considered as the starting point of the neoliberal era, as it promoted trade liberalization. As soon as the World Trade Organization (WTO) was created, South Africa's legislation aligned with the TRIPS agreement and also developed strong relations with the United States, with the 1994 Agreement on Government Procurement (GPA) for instance. In this rather conducive context, many multinational pharmaceutical companies have invested in South Africa, obtaining the licences which had previously been granted to local manufacturers during Apartheid.

Nevertheless, the rising opposition from civil society undermined the relations between the state and the pharmaceutical industry. In the second half of the 1990s, the South African population was facing a growing AIDS epidemic without any access to treatments in the public health sector, since the government had adopted a "denialist" position and justified its refusal to provide the population with antiretroviral medicines by arguing that Western Industry had brought the disease to Africa to open new markets (Fassin 2006). Opposition from civil society came to fruition during the "Pretoria trial" when the South African government, supported by civil society, faced 39 pharmaceutical companies in CCcourt. This law case also shed a light on access issues at the international level, as shown by the adoption of the Doha Declaration in 2001. This Declaration aimed at strengthening the flexibility of TRIPS agreements' principles and emphasizes states' right to use this flexibility principle. It epitomized international debates on global health goods and highlighted the issue of multinational companies' social responsibility.

Since then, the narratives around access to medicines have posited a strong opposition between state and industry. According to these narratives, the state's duty should be to limit intellectual property rights. The 1999 report on the implications of TRIPS for access to medicines commissioned by the World Health Organization and the World Trade Organization (WHO and WTO 1999) was followed by the creation in 2003 of a WHO IP Rights, innovation and public health. Its report (WHO 2006) showed that patents are not an incentive to innovation in developing countries. In 2008, resolution WHA61.21/62.16 was passed by the World Health Assembly, calling for the creation of a global strategy and a public health plan. In 2015, a United Nations' Secretary-General's High Level Panel on access issues was set up to try and strike a balance between intellectual Property (IP) and health rights.

\section{In South Africa, a policy forum based on a binary vision of medicines}

17 The opposition between access to medicines and patent protection has structured the policy forum in South Africa. A range of reforms have aimed at redefining the respective prerogatives of the state and of industry as regards access to antiretroviral 
medicines. Nevertheless, the attempts to regulate prices and competition, with for instance the attempts to implement a compulsory Benchmarking Methodology in the public market or the Health Market Inquiry undertaken by the DoH in order to strengthen the competition law, or Intellectual Property Law have not been successful. This triggered a series of scandals that the difficulties of Intellectual Property reform illustrate well. Even though the Doha Declaration insists on the importance of resorting to TRIPS flexibility to increase access, South Africa is still striving to align its IP law with the Doha Declaration. In spite of the world-famous Pretoria trial of 2001, many stakeholders are reluctant to apply the TRIPS flexibility principle to the South African IP law.

In 2008, under the influence of the Department of Health, the Department of Trade and Industry launched a discussion to align Intellectual Property policy with Doha Principles. A Green Paper came out in 2013 and called for stakeholders' submissions. Two main advocacy coalitions emerged: on the one hand, the civil society "triad" made up of advocacy groups Section 27, Treatment Action Campaign and Médecins sans Frontières strongly supported the paper with their campaign "Fix the Patents Law," calling for a gradual process of elimination of patents by de-connecting intellectual property issues from the price of medicines. This "epistemic community" (Haas 1992) also includes most academics and importers of generic medicines which are generally produced in India - even if the latter, by shifting to biosimilar production, ${ }^{3}$ is more and more interested in patenting opportunities. On the other hand, multinational companies represented by their industrial association oppose the reform, arguing that it would not be enforceable, due to lack of capacities. The South African Department of Science and Technology and part of the Department of Trade and Industry also questioned the IP reform project, arguing that it would lead to major divestment from South Africa. More discretely, South African generic manufacturers promote the conservation of Intellectual Property, since voluntary licences from originators are their major pipelines. As a consequence, the Intellectual Property reform proposal triggered a wide variety of positions which were overshadowed by the 2014 "Pharmagate," when the leaking of a confidential document from a US consulting office, which outlined how major originator companies aimed to counter the Intellectual Property reform proposal, caused a major scandal, contributing to an ostensible break-up between the state and the pharmaceutical industry. Since then, the promoters of access to medicines have been able to influence industrial stakeholders more strongly, as will be shown below.

\section{Towards organizational change: health institutions at the core of pharmaceutical-market management in South Africa}

\section{When the pharmaceutical market is vested with the Department of Health}

19 The striking politicization of health in South Africa has resulted in the growing influence of the DoH in pharmaceutical public markets. Health is presented by the 
Health Minister as the key to achieving socio-economic rights by the fulfilment of constitutional rights:

It is particularly concerning that many participants appear to lack an understanding of both the principles of social solidarity, and the need for redistributive justice. These principles are enshrined in the Constitution and are central to redressing the pervasive, historically entrenched inequality. It is expected that stakeholders will have a variety of economic, political and philosophical perspectives, the trend towards a conservative approach that lauds free market principles is concerning, particularly given the internationally recognised failings of the healthcare market. (DoH 2015: 2)

This use of the Constitution rests on the fact that the legitimacy of the post-Apartheid state is based on the duty to fulfil the social contract. Health is presented as a catalyst for equality and, as such, should be accessible to all:

It is also important that the Inquiry focuses on the notion of health as a public good. This is important because the State is expected to put into place institutional, organisational and regulatory mechanisms to support the progressive realisation of the right to healthcare for every citizen. (DoH 2015: 5)

In South Africa, the Gini coefficient is one of the highest in the world and the claim for equality is at the core of ANC legitimacy. The NHI does not consist in growing public investment in health but in the state's ability to monopolize parts of private capital (in infrastructures, skills and funding) to re-orientate it towards a system of social solidarity. As a civil servant at the DoH argued, "you know that if poor people do not manage to reach basic welfare through their jobs and education, they might resort to violence." (DoH Civil Servant 2016)

Our research shows that the Department of Health appears as an ANC stronghold and acts as a game-ruler within government. A civil servant from DoH explained that the DoH had a strong influence on the other departments: "You know it's easy since we are from the same party. In other countries like France with many parties they would not let regulations pass as it happens for me at the Parliament. I hardly meet a resistance when I suggest a paper." (DoH Civil Servant 2016)

Improving access to health stands as a central political strategy. It takes the form of a struggle against the private health sector and the re-designing of public domain frontiers - at least symbolically: "NHI is a political decision of a nation hungry for justice and equality. It is based on political will and should not be subjected to obstacles driven purely by greed and self-interest of a selected few." (DoH Civil Servant 2016) It may also involve the shaming of pharmaceutical industry: "Two years ago, I was regarded as exaggerating or outright insane by some, when I spoke openly against Pharmaceutical companies that were planning a price onslaught against us. Today, that onslaught which I had foreseen is here with us." (Motsoaledi 2015a)

The Department of Health has been redesigning its mandate through its intervention in the public market of antiretroviral treatments. A significant milestone was the relocation of pharmaceutical contracts into the Department of Health. Previously, medicine procurement in the public sector had been the responsibility of the National Treasury, which was more broadly responsible for the management of public contracts. In 2009, a Ministerial Task Team advised that a Central Procurement Agency, directly responsible towards the Minister of Health, should be created. Its core structure, the Directorate of Affordable Medicines, was approved in 2011 by the National Health Council. From then on, it started to manage public tenders independently from the 
National Treasury. A, who is a close observer of the government (Observer A 2015), explained that a blame game was going on between the Department of Health, the National Treasury and the Department of Trade and Industry. The latter two were put on the back burner as mere observers by the former, as shown by the example of the preference point system. Bids are awarded according to a 90/10 preference-point system. 90 points are allocated to price levels and 10 points to the companies' B-BBEE status level (which promotes the development of Black Business in South Africa). Historically, these B-BBEE points have been promoted by the Department of Trade and Industry, using section 5(2) of the Preferential Procurement Policy Framework Act (PPPFA) 2000, in order to improve the trade balance by developing local industry. Even though an unpublished DTI study showed that 20 B-BBEE points would still be cost effective, the Department of Health immediately limited this preferential procurement by establishing a maximum price which cannot exceed $10 \%$ of the price premium.

Moreover, the Department of Health was able to capture a set of regulatory processes and is consequently omnipresent in current pharmaceutical reforms. For instance, the Intellectual Property draft was released by the DTI and was supposed to be a trade issue. Nevertheless, the Department of Health's influence is strong. As an interviewee from French diplomacy put it: "Actually it is a DoH paper." (French Diplomat 2014) Our research shows that many civil servants at the DTI share views with the DoH and act as a relay for it. All in all, the Department of Health has gradually strengthened its leadership in the pharmaceutical sector in South Africa by vesting the market.

\section{The standardization of medicines in the public market: a low-cost policy}

The DoH resorts to new-public-management techniques to implement its universalaccess policy. We focus here on the techniques used to enable access to medicines within the public market of ARV treatments. These instruments avoid the controversial process to formulate political compromises and contribute to building a specific framing of access based on new public management.

In order to provide the bulk of patients with generic medicines, the guidelines have promoted the growing standardization of treatments - more exactly of therapeutic classes - on the basis of strict equality of patients at the lowest price. The HIV/AIDS burden on the health budget has kept increasing, as CD4 count is planned to be removed as an eligibility criterion ${ }^{4}$ and $\operatorname{PrEP}^{5}$ is being tried in some programmes for vulnerable individuals. This medicine-focused strategy has been a growing financial burden for the Health budget, as it has increased by $7 \%$ to $10 \%$ in the last 7 years, while the Health budget has declined as a proportion of the National Budget (Health Budget 2015). In such a context, the reduction of price per capita has been at the core of the antiretroviral medicines roll-out strategy; for instance, $\mathrm{Y}$, a chief Manager at the DoH opened a meeting telling me "do you know that in South Africa we have the cheapest ARVs in the world?" (DoH Manager Y 2014). This means that universal access to medicines may be financially feasible only if prices are very low and monitored by newpublic-management rationality. As a consequence, the public procurement of antiretroviral treatments is based on a price-focused selection process.

Indeed, the National Drug Policy articulated by the DoH is based on a tryptic: access, quality and rational use. Access and rational use are defined according to price issues: 
access is defined as "equitable availability and affordability of essential drugs" while rational use is said to be "the promotion of therapeutically sound and cost-effective use of drugs by health professionals and consumers" (National Drug Policy 1996). The issue of the quality of the medicines is therefore firmly framed by the issue of price: only affordable medicines are to be provided. The emphasis on prices is omnipresent, as revealed in a slideshow presented by the Central Drug Programme: 10 slides out of 36 address prices and cost-effectiveness (PTC Workshop 2015).

This price-focused strategy stems from a twofold movement of standardization of medicines and depoliticization of the selection process. Indeed, it enables the government to focus on the price of medicines and thereby to avoid the broader issues of patent law and infrastructural failure in South Africa. The process of medicine selection is extremely technical. An interview with J, a manager at Central Drug Procurement (CDP) at the Department of Health (CDP), shows how quantitative medicines selection is:

We do some pharmaco-economic analysis and the medicine might prove to be cost effective but we might not be able to afford it. We really look at affordability. So when we have big shifts in treatments we also look at impact analysis to see what will be the impact on the budget. So something might be cost effective but not affordable for us. The question is: can you use this new commodity with your budget? First we look at the clinical evidence: is it safe? And then we go to the cost issue. We do a lot of cost minimization. If you have medicines A and B and the outcomes are barely the same, we compare them. And then once we know it's cost effective we'll see if it's affordable for us to use that given the budget that you have. (CDP Manager J 2015)

The semantic fields used in the whole interview are linked to data, bureaucracy, prices and guidelines. New-public-management techniques are broadly used during the drug selection. It highlights the focus on efficiency, cost-effectiveness and "optimality". The CDP resorts to a range of instruments and techniques in order to objectify the selection process. The members of the National Essential Medicines List Committee (NEMLC) and of the Pharmacy and Therapeutics Committee (PTC) sign Declaration of Interest and Confidentiality forms to ensure transparency, and recruitment process are based on tangible signs of technical skills: most civil servants at the Department of Health have a $\mathrm{PhD}$ in Pharmacy or Medicine and have an academic background. Furthermore, medicine standards are at the core of medicine selection: the Essential Medicines List (EML) and Standard Treatment Guidelines ensure the standardisation of care: "Guidelines aim to standardise care, reduce local variation (equity), and improve health outcomes". ${ }^{6}$ The methods used to select medicines are based on quantitative pharmacoeconomic analysis such as cost-effectiveness analysis. Evidence-based medicine is also at the core of medicines selection and shows the technicity of decision-making; the Essential Drug List (EDL) uses the "Strength of Recommendation Taxonomy" (SORT) which aims at rationalizing many types of evidence through a unique taxonomy.

The development of a National Health Insurance (NHI) has even increased medicine standardization. The variety of medicines supplied by the government is to be reduced thanks to the establishment of therapeutic classes. It means that within a basket of medicines with similar indications, only one will be included within public supply: "these therapeutic classes have been designated where none of the members offer a significant benefit over the other registered members of the class" (DoH, 2012). The 
Pharmaceutical Task Group, an industrial working group, has noticed in a submission that:

the medicine options currently available to patients in the public sector are considerably wider than the Essential Medicines List, to which the White Paper refers at a number of points [...]. The PTG recommends that [...] the NHI should seek to broaden the accessibility of different medicines for different patient needs, rather than attempting to ration or restrict this. (Pharmaceutical Task Group 2015: 10-11)

This quote is telling, since it highlights a paradox inherent to NHI: the implementation of a unique healthcare system, said to be the fulfilment of universal access, is likely to reduce the variety of medicines available to patients. Moreover, attempts by civil society to protect the variety of supply come up against closed institutions and practices. For instance, the South African National AIDS Council (SANAC), which is a platform designed to build a comprehensive response to the AIDS epidemic, does not always take into account some interventions from civil society, as was suggested by the Treatment Action Campaign (TAC Provincial coordinator 2015).

. An employee at Doctors without Borders (MSF) South Africa even explained that "any special medical condition is out of control in the public sector." (MSF Employee 2015) In other terms, in order to achieve a strong political project, the South African state reduces its prerogatives over medicines in a defined and restricted perimeter.

\section{The antiretroviral public market as a nexus between state and industry}

\section{A myriad of relational contracts between the Department of Health and a few empowered companies}

In contrast with the transnational policy forum around access presented in the first part of this article, I now wish to demonstrate that the public market of medicines is a major arena of negotiation: this is where already-identified players bargain the material and symbolic dimensions of medicines. Negotiation arenas, where the implementation of policy is worked out, are narrower than policy forums.

The nexus between state and industry is located within the public market, more accurately during the tendering process. The selection of bidders is not merely based on cost-oriented criteria but also on tight relationships between the procurement department and a small number of companies. My study shows that state regulation consists in the social delimitation of the public market. Since Department of Health influence over the market of medicines is strengthening, companies attempt to get closer to the Central Procurement Unit at the DoH. More and more often, they underline their links to the public sector and try to act in compliance with the state. Most of my interviewees from pharmaceutical companies explained that the public sector has become central to their business. As a manager in a pharmaceutical company asserted, "When NHI is implemented [...] It will be the moment when our relations with the State will count." (Pharmaceutical Company Manager 2015) Building relations with the State is critical to maintaining a minimum of predictability and to secure investment in some types of medicines such as antiretroviral medicines. The same manager explained: 
Why do companies stick to the state? Because there is so much uncertainty concerning National Health Insurance. Then, I think that we will have to take more and more into account the social responsibility required to invest in emerging countries. (Pharmaceutical Company Manager 2015)

Companies endeavour to get closer and closer to DoH civil servants. One of the interviewees said that he came to visit the Health Minister at the hospital, while the aforementioned manager explained that his company contacted the Department of Health right after the 2014 Pharmagate:

We just asked for a face-to-face meeting with the Deputy Director General in order to show them that we are not opposed to them. We finally agreed on looking at DoH policy. But DoH was the first state department we came to see. I have to say that [Name of his company] has been the only one to get a face-to-face meeting with them. (Pharmaceutical Company Manager 2015)

The growing importance of the health public sector has resulted in a strong competition between industrial stakeholders to access public tenders. The necessity of cutting costs has implied the selection of foreign generic companies. The procurement department - a division within the DoH - has favoured new types of providers, namely generic multinational companies, generally from India because of their price competitiveness. The public supply of medicines is locked around specific policy brokers who come from industry and try to monopolize the market while they reinforce the public sector's purchase power. A civil servant at the DoH explained that the DoH had developed strategies to attract new importers:

At that time [in 2008] local companies were the main suppliers. We said: "ok, if you want us to buy local then give us the money to buy enough medicines for all." I went to India and asked them why they were not interested in exporting to South Africa since we are the biggest market for ARVs. They replied that in South Africa the public market was only taking local manufacturers. Indeed, local companies were creating pressures on competitors. We decided to change it and we integrated the Indians into the tenders. (DoH Civil Servant 2016)

Therefore, the state's capacity to implement its policies is essentially linked with its dependence on multinational generic companies which, by importing cheap Active Pharmaceutical Ingredients (APIs) from India and China, are able to provide public tenders with the cheapest antiretroviral medicines (Kudlinski 2012). Avoiding originators and local manufacturers in favour of multinational generic makers has been essential to the implementation of access to antiretroviral medicines, in spite of the Department of Trade and Industry's developmental policies.

These companies would have limited interest in entering low-profit bids with strong uncertainty, since the ARV tender lasts only two years. By resorting to strategic use of Black Economic Empowerment, that is to say regulation which promotes the transfer of stakes in white-owned businesses to a new class of black investors, packaging selection (which can favour specific providers) and continuous pressure on prices, the public tenders tend to favour a limited number of companies through relational contracts. During the interviews, this category of stakeholders describes strong links with the state: a CEO of one these pharmaceutical companies evokes a "relationship": "we get on well with the Department of Health, we actually get on well". His emphasis on "transparency" and on the predictability of their agreements "we have always been on tenders since 20 years" shows that the development of the partnership stands for a long-lasting agreement with the state (Pharmaceutical Company CEO 2015). Moreover, their relations with the state are not channelled by industrial associations. They resort 
directly to a limited number of key stakeholders at the DoH, as V, an employee of an industrial association explained:

- Do you resort to an umbrella body to defend your interests?

- Sometimes, it's better to act on your own. Generally that's what we do since we

already have strong relations with the government. (Employee V 2015a)

Indeed, $\mathrm{V}$ suggested that the relations between the state and businesses have a strong personal dimension:

- You see, the relations that these companies have with the state are more ...

personal. (Employee V 2015b)

These stakeholders also have advisory roles towards the Department of Health and the Department of Trade Industry. In fact, an employee of Aspen Pharmacare is an advisor to the Trade Minister. These empowered companies define themselves as "practical" organizations which can provide the state with technical guidance since, as S, a manager in such an empowered company argued, "in the DoH, they are all academics [...] they are a liberation party, they do not know how to design policies." (Manager S 2015)

The government has undertaken the construction of a state-owned plant to produce antiretroviral medicines' APIs nationally and provide its entire population with treatments. Most of my interviewees call into question the government's ability to understand market dynamics. As manager S argued, "Government wants its own facility, it's indicated in the $10^{\text {th }}$ point of healthcare reform. The big issue is that they will never manage to supply for all South Africans. This policy doesn't make any sense, its unique goal is to appeal to people." (Manager S 2015) These critical viewpoints show how state and industry are intertwined in policy implementation and shows that industry is able to engage with health policy-makers.

\section{The public tenders as a state disciplinary apparatus}

The companies' position is ensured by an implicit loyalty towards the state. If they break these relations by adopting an ill-adjusted behaviour, such as setting high prices or mismanaging their supply chain, they are likely to lose their contracts. In his 2017 budget speech, Health Minister Aaron Motsoaledi offered a pungent criticism of pharmaceutical industry's role on medicine pricing, but ended up listing companies and private health providers who have been contributing to a Fund. By making these companies visible and presenting them as models, the state labels them as "good pupils." Contrariwise, some companies can be blacklisted by the government. The necessity to be seen "on the side of the state" stems from the fear of being frozen out of the public market.South African company Adcock Ingram, for instance, was suddenly kicked out of the tenders after its prices were not considered competitive enough by the tender department.

44

All in all, these elements suggest a strong state regulation in the ARV market. Thanks to the development of a benchmarking methodology project to ensure low prices and even the establishment of a Health Competition Inquiry, the DoH has been able to force the private health market into complying with price requirements. In 2014, the South African Competition Commission started a market inquiry to look into high prices in the private healthcare sector, which aimed at investigating the general state of 
competition in the health market. This Inquiry betrays the growing reach of the National Department of Health which aims at imposing medicines' affordability even in the private healthcare sector. The benchmarking methodology is a telling example, constituting a sort of "ghost regulation". As a civil servant at the DoH argued, the methodology has never been really used, since companies virtually respect the principle of low prices:

You know, we initially designed an International Benchmarking Methodology for originators, to control prices. They have to apply by giving prices of their country markets and then if prices suggested in South Africa are higher, we look into it and try to investigate. But they do not want to explain why it may be more expensive in South Africa so they automatically suggest lower prices. We never need to resort to methodology actually. (DoH Civil Servant 2015)

Within the ARV policy arena, industry ends up accepting the rules of the game and even internalizes control. All in all, industrial stakeholders accept state intervention not through unilateral domination, but by voluntarily accepting specific rules and regulations for determined issues and products in exchange for access to the South African market. Companies accept these rules in this specific arena dedicated to access to antiretroviral medicines and let the state have hold on patented medicines as if, more or less symbolically, they were falling into the public domain. The partial requalification of medicines as a public good can be observed through the state's ability to label medicines as belonging to the public domain, as shown by two examples. The first is the 2008 Intellectual Property Rights from Publicly Financed Research and Development Act, known as the IRP Act, which came into effect on 2 August 2010 and ensures that intellectual property emanating from publicly-financed $R \& D$ is protected and commercialised for the benefit of the people of South Africa, knowing that the state retains 'walk-in rights' for health. ${ }^{7}$ A second example regards public tenders: an originator company has granted a patented medicine to the public tenders. It has given it off label and the state takes care of its commercialization which is usually the purest expression of industrial property. As an employee of this company argued, "that's indirect marketing! The state takes care of communication for us!" (Pharmaceutical Company Employee 2015)

\section{Conclusion}

The growing commodification of medicines questions the scope of state prerogatives in the health sector. In such a context, collective action to enable access to medicines is channelled by critiques of neoliberalism in favour of a traditional vision of the "welfare state" as modelled by Esping-Andersen, announcing the imminent collapse of neoliberalism (Wallerstein 2015). On the contrary, this article shows, through the example of ARV public-sector supply in South Africa, that medicine supply is organized in accordance with a neoliberal rationality. Indeed, the South African AIDS policy is not destroyed but designed by neoliberal mechanisms. Indeed, the access policy is paradoxically based on a quantitative vision of medicines, which emphasizes its price and calls for an ongoing standardization of treatments. These one-size-fits-all ARV medicines betray a macroscopic vision of health, far from an anthropological perspective of patients, as a professor at the School of Public Health at the University of Western Cape argued (UWC Professor 2015). In a resource-constrained environment, traditional welfarism is replaced by ad hoc mechanisms. In South Africa, this situation 
has resulted in ambiguous but tight relations between state and industry, where the state has had to engage with industry to implement its access policies, from conflicts in policy forum to cooperation in a restricted policy arena: the public market of antiretroviral medicines. The latter has enabled the Department of Health to design new price standards and to challenge the configuration of patents. As a conclusion, we suggest that the South African government fulfils its universal access policy by vesting the market of medicines. This study is in line with Ferguson's approach of neoliberal health policies. The author claims that these policies "may be transforming the field of political limits and possibilities" (Ferguson 2015). Indeed, the South African government's ability to adopt industry's narratives to weigh in negotiations stands for a concrete and efficient way of avoiding the bottlenecks implied by litigation around patents. This behaviour may pave the way for other Southern countries which do not have strong and independent industrial capacities.

\section{BIBLIOGRAPHY}

Boidin, Bruno. "Libéralisation et accès des pays pauvres à la santé. Quelle responsabilité des droits de propriété intellectuelle et des firmes?” Mondes en développement 120 (4) 2002: 63-74.

Boidin, Bruno. "Économie politique de la santé comme bien public Mondial." Revue de la régulation 17 (2015). DOI: 10.4000/regulation.11128

Bond, Patrick. Talk Left, Walk Right: South Africa's Frustrated Global Reforms. Scottsville, South Africa: University of KwaZulu-Natal Press, 2004.

Boussaguet, Laurie and Pierre Muller. "L'impact du forum politique sur la formulation des politiques publiques.” Politiques et Management public 23 (3) 2005: 41-59. https://halsciencespo.archives-ouvertes.fr/hal-01020878

Boyer, Robert. Économie politique des capitalismes. Paris: La Découverte, 2015.

Correa, Carlos (ed.) Pharmaceutical Innovation, Incremental Patenting and Compulsory Licensing. Geneva: The South Centre, 2013.

Chapman, Audrey. "The impact of reliance on private sector health services on the right to health." Health and Human Rights 16 (1) 2014: 122-134.

Collier, Stephen J. Post-Soviet Social: Neoliberalism, Social Modernity, Biopolitics. Princeton, NJ: Princeton UP, 2011.

Dardot, Pierre and Christian Laval. The New Way of the World: On Neoliberal Society. London: Verso, 2013.

De Wet Phillip, “Motsoaledi: Big pharma's ‘satanic' plot is genocide," Mail and Guardian, 17 January 2014.

DoH. "Standard Treatment Guidelines and Essential Medicines List for South Africa. Hospital Level. Adults. 2012 Edition.” The National Department of Health, 2012. http://apps.who.int/ medicinedocs/documents/s21732en/s21732en.pdf 
DoH. "National Department of Health: Response to submissions made to the Competition Commission Inquiry Panel", Department of Health of the Republic of South Africa, 2015. http:// www.compcom.co.za/wp-content/uploads/2015/05/NDoH-Response-toSubmissions_20150419_v1_MN.pdf

Dozon, Jean-Pierre et Didier Fassin. "Raison épidémiologique et raisons d'État. Les enjeux sociopolitiques du SIDA en Afrique.” Sciences sociales et santé 7(1) 1989: 21-36.

Evans, Peter. “Is an Alternative Globalization Possible?" Politics \& Society 36 (2) 2008: 271-305.

Fassin, Didier. "Politique des corps et gouvernement des ville." In Didier Fassin (ed.). Les figures urbaines de la santé publique. Paris: La Découverte, 1998: 7-46.

Fassin, Didier. Quand les corps se souviennent. Expériences et politiques du sida en Afrique du Sud. Paris: La Découverte, 2006.

Ferguson, James. Give a Man a Fish: Reflections on the New Politics of Distribution. Durham: Duke UP, 2015.

Ford, Nathan, Graeme Meintjes, Anton L. Pozniak, Helen Bygrave, Andrew Hill, Trevor Peter, Mary-Ann Davies, Beatriz Grinsztejn, Alexandra Calmy, N Kumarasamy, Praphan Phanuphak, Pierre deBeaudrap, Marco Vitoria, Meg Doherty, Wendy Susan Stevens and George Sibery. "The future role of CD4 cell count for monitoring antiretroviral therapy." Lancet Infectious Diseases 15(2) 2015: 131-248.

Fouilleux, Ève. "Entre production et institutionnalisation des idées: la réforme de la politique agricole commune." Revue française de science politique 50(2) 2000: 277-305.

Gray, Andy, Yousuf Vawda and Caron Jack. "Health Policy and Legislation”. In Ashnie Padarath and René English (ed.). South African Health Review 2012/13. Durban: Health Systems Trust, 2013.

Hagmann, Tobias and Didier Péclard. "Negotiating statehood: Dynamics of power and domination in Africa." Development and Change 41(4) 2010: 539-562.

Hall, Peter and David Soskice. Varieties of Capitalism: The Institutional Foundations of Comparative Advantage. Oxford: Oxford UP, 2001.

Hodgson, Tim. "The impact of socio-economic rights on competition law and policy: who pays and who profits?" Constitution Hill, 19 March 2015. Unpublished document.

Jessop, Bob. "Putting neoliberalism in its time and place: a response to the debate." Social Anthropology 21(1) 2013: 65-74,

Jobert, Bruno. “Le retour du politique.” In Bruno Jobert (ed.), Le Tournant néolibéral en Europe. Paris: L'Harmattan, 1994: 9-20.

Karamessini, Maria. "Sovereign debt crisis: an opportunity to complete the neoliberal project and dismantle the Greek employment model". In Steffen Lehndorff (ed.). A Triumph of Failed Ideas: European models of capitalism in the crisis. Brussels: European Trade Union Institute, 2012: 155-83.

Kudlinski, Andre. "Harmonizing national policies for healthcare, pharmaceutical industry and intellectual property: the South African experience." In Frederick M. Abbott, Carlos M. Correa and Peter Drahos (eds.). Emerging markets and the world patent order: the forces of change. Cheltenham: Edward Elgar, 2013: 255-85.

Lawrence, Thomas and Roy Suddaby. "Institutions and Institutional Work." In Stewart R. Clegg, Cynthia Hardy, Thomas B. Lawrence and Walter R. Nord (eds.). Handbook of Organization Studies. London: Sage, 2006: 215-54. 
Legido-Quigley, Helena, Marina Karanikolos, Sonia Hernandez-Plaza, Claudia de Freitas, Luis Bernardo, Beatriz Padilla, Rita Sá Machado, Karla Diaz-Ordaz, David Stuckler, and Martin McKee. "Effects of the financial crisis and troika austerity measures on health and health care access in Portugal." Health Policy 120(7) 2016: 833-9.

Haas, Peter. "Introduction: epistemic communities and international policy coordination." International Organization 46(1) 1992: 1-35.

Marais, Hein. South Africa: Limits to Change. The Political Economy of Transition. New York: Zed Books, 2001.

McGregor, Sue L.T. "Neoliberalism and health care." International Journal of Consumer Studies 25(2) 2001: 82-9.

Mladenov Teodor. “Neoliberalism, postsocialism, disability." Disability \& Society 30 (3) 2015: 445-59.

Motsoaledi, Aaron. "Health Department Budget speech", National Assembly, 5 May 2015a. https://www.gov.za/speeches/minister-aaron-motsoaledi-health-dept-budget-vote-201516-5may-2015-0000

Motsoaledi, Aaron. "Health Budget Speech." Debate on the health budget vote, National Assembly, 10 May 2016. https://www.health-e.org.za/wp-content/uploads/2016/05/MinistersSpeech-Version-10-May-2016-09h45-Final-for-circulation.pdf

Nay, Olivier and Andy Smith. Le gouvernement du compromis. Courtiers et généralistes dans l'action politique. Paris: Economica, 2002.

Obrist, Brigit, Nelly Iteba, Christian Lengeler, Ahmed Makemba, Christophe Mshana, Rose Nathan, Sandra Alba, Angel Dillip, Manuel W. Hetzel, Iddy Mayumana, Alexander Schulze and Hassan Mshinda. "Access to Health Care in Contexts of Livelihood Insecurity: A Framework for Analysis and Action." PLoS Medicine 4 (10) 2007: 1584-8.

Orsi, Fabienne. "Penser la propriété commune, un nécessaire changement de cadre d'analyse," Document de travail ANR - Propice, mai 2012. http://anr-propice.mshparisnord.fr/docus-pdf/ Orsi_WP_ANR_PROPICE.pdf

Peck, Jamie. "Neoliberalizing states: thin policies/hard outcomes” Progress in Human Geography 25 (3) 2001: 445-55.

Peck, Jamie. “Explaining (with) neoliberalism.” Territory, Politics, Governance 1 (2) 2013: 132-57.

Pharmaceutical Task Group (PTG), "Comments in response to the White Paper on National Health Insurance." Government Gazette n 39506, 11 December 2015. https://ipasa.co.za/Downloads/2016may-nhi-white-paper/20160530-PTG-Submission-NHI-White-Paper-Submission.pdf

PTC Workshop. "Introduction to the Essential Drugs Programme." North West Province PTC Workshop, 31 March 2015. Unpublished document.

Srinivas, Smita. Market Menagerie: Health and Development in Late Industrial States. Stanford: Stanford UP, 2012.

Sweet, Cassandra and Keshab Das. "Barriers to Indian Pharma Post-2005." In Cristina Possas and Bernard Larouzé (ed.). L'accès aux antirétroviraux dans les pays du sud. Paris: ANRS, 2013, 109-124.

Vawda, Yousuf. "Pharmaceutical Innovation, Incremental Patenting and Compulsory Licensing Country Case Study: South Africa.” Working Paper, Durban, 2015. http:// ipublichealth.weebly.com/uploads/1/2/8/3/12835706/sa_patenting.pdf 
Wallerstein, Immanuel (ed.) The World is Out of Joint: world-historical interpretations of continuing polarizations. Boulder: Paradigm Publishers, 2015.

WHO 2006. "Public health: innovation and intellectual property rights. Report of the Commission of Intellectual Property Rights, Innovation and Public Health.” World Health Organization, 2006. https://www.who.int/intellectualproperty/report/en/

WHO and WTO. "Globalization and access to drugs: implications of the WTO/TRIPS Agreement." Geneva: World Health Organization, 1999. http://www.who.int/iris/handle/10665/63905

\section{Interviews}

CDP Manager J. Interview with the author, Pretoria, June 2015.

DoH Civil Servant. Interview with the author, Pretoria, November 2016.

DoH Civil Servant. Interview with the author, Pretoria, September 2015.

DoH Manager Y. Interview with the author, Pretoria, March 2014.

Employee V. Interview with the author, Johannesburg, August 2015b.

Employee V. Interview with the author, Johannesburg, May 2015a.

French Diplomat. Interview with the author, French embassy, Johannesburg, March 2014.

Manager S. Interview with the author, Centurion, August 2015.

Motsoaledi. Interview with the author, Johannesburg, 2015b.

MSF Employee. Interview with the author, Johannesburg, August 2015.

Observer A. Interview with the author, Centurion, September 2015.

Pharmaceutical Company CEO. Interview with the author, Johannesburg, September 2015.

Pharmaceutical Company Employee. Interview with the author, Pretoria, October 2015.

Pharmaceutical Company Manager. Interview with the author, Centurion, August 2015.

Professor V. Interview with the author, Durban, April 2015.

TAC Provincial coordinator (Gauteng province). Interview with author, Johannesburg, September 2015.

UWC Professor. Interview with the author, Cape Town, April 2015.

\section{NOTES}

1. The 1997 South African Intellectual Property Laws Amendment Act was passed hurriedly as an alignment to the TRIPS agreement. It took the form of a set of compromises between the two major parties, which did not incorporate TRIPS flexibilities into the law.

2. The notions of policy forum and policy/negotiation arena were offered then refined by public policy scholars Eve Fouilleux, Bruno Jobert and Pierre Muller (Boussaguet et Muller 2005; Fouilleux 2000; Jobert 1994). These authors investigate the ways public policies are legitimized, negotiated and implemented. Jobert (1994) makes a distinction between formal negotiation arenas and what he calls policy forums (forums politiques). The notion of negotiation arena refers to places where individuals negotiate the material and concrete conditions of policy implementation. While the arenas are usually limited to formal processes and decision makers, 
the notion of policy forum applies to broader aspects of policy making. It refers to the places which are vested by a diversity of actors such as public servants and experts as well as opinion leaders and the media, in which they incrementally develop common definitions of social life and common mindsets, by questioning existing rules and creating new ones.

3. A biosimilar is a biological medical product that is almost an identical copy of an original product, by contrast with simpler, chemical generic medical products.

4. See the abstract of Ford et al (2015): "For more than two decades, CD4 cell count measurements have been central to understanding HIV disease progression, making important clinical decisions, and monitoring the response to antiretroviral therapy (ART). In well-resourced settings, the monitoring of patients on ART has been supported by routine virological monitoring. Viral load monitoring was recommended by WHO in 2013 guidelines as the preferred way to monitor people on ART, and efforts are underway to scale up access in resource-limited settings".

5. Pre-exposure prophylaxis or PrEP is the use of an antiretroviral medication to prevent the acquisition of HIV infection by uninfected persons. See "Pre-exposure prophylaxis" on the WHO website: http://www.who.int/hiv/topics/prep/en/

6. CPD presentation, Pretoria, June 2015.

7. See the University of Cape Town website: http://www.rci.uct.ac.za/rcips/ip/pfbill.

\section{ABSTRACTS}

One of the modalities of access to medicines in South Africa consists in the paradoxical delegation of regulatory functions to non-state actors - namely, but not only, industry. Drug policies in neoliberal globalized states are characterized by their insertion into a global trade system which promotes a growing commodification of medicines. At the same time, calls for the reform of national drug policies rise significantly. State formation in South Africa has been characterized by continuous negotiations and compromises with business, which at first sight questions the possibility of access policies. Opening the black box of the South African state amounts to demonstrating the state's ability to roll out a political project which endeavours to have the pharmaceutical industry adopt the notion of universal access in a neoliberal context. This article attempts to shed a light on access mechanisms through the analytical deconstruction of the public market of antiretroviral medicines as a set of intertwined social relations. In South Africa, the role of industry, as heterogeneous as it is, has been deeply ambiguous and often denounced by civil society. Still, its role has been critical to ensure the supply of medicines. As a result, the Department of Health has been broadly dependent on industry, regarding the innovation agenda, the security of supply and industrial policy.

Une des modalités d'accès aux médicaments en Afrique du Sud consiste dans la délégation paradoxale - de fonctions régulatoires à des acteurs non-étatiques, en particulier - mais pas seulement - les industriels. Les politiques du médicament dans les Etats globalisés néolibéraux sont caractérisées par leur insertion dans un système commercial mondial qui promeut la marchandisation croissante des médicaments. Parallèlement, les demandes de réforme des politiques du médicament conduites au niveau national ont crû de manière significative. La formation de l'Etat sud-africain a été marquée par des négociations continues et des compromis avec les entreprises, ce qui pourrait sembler susceptible, de prime abord, de remettre en cause la 
possibilité-même de mettre en œuvre des politiques d'accès aux médicaments. Lorsqu'on ouvre la boîte noire de l'Etat sud-africain, on peut constater que l'Etat s'emploie à mettre en œuvre un projet politique visant à ce que l'industrie pharmaceutique adopte le principe de l'accès universel aux médicaments dans un contexte néolibéral. Cet article met en lumière les mécanismes d'accès aux médicaments en analysant le marché public des traitements antiviraux comme un ensemble de relations sociales entremêlées. En Afrique du Sud, le rôle des industriels - quelle que soit leur hétérogénéité - a été profondément ambigu, et dénoncé à ce titre par la société civile. Toutefois, le rôle de l'industrie pharmaceutique a été décisif pour garantir l'approvisionnement en médicaments. Il en résulte que le Ministère de la santé sud-africain a été largement dépendant des industriels en ce qui concerne aussi bien l'innovation que la sécurisation de l'approvisionnement et le développement industriel.

\section{INDEX}

Keywords: HIV/AIDS, patents, South Africa, TRIPS, access to medicines, pharmaceutical industry, neoliberalism

Mots-clés: VIH/SIDA, brevets, Afrique du Sud, ADPIC, accès aux médicaments, industrie pharmaceutique, néolibéralisme

\section{AUTHOR}

\section{CHARLOTTE PELLETAN}

Charlotte Pelletan is a Ph.D student in Political Science at the Bordeaux Institute of Political Science. Her Ph.D. research aims at re-thinking access to medicines through the reconnection of health systems, the architecture of the pharmaceutical industry and innovation dynamics. She co-wrote with Palesa Sekhejane (HSRC) a book chapter entitled "HIV and AIDS Triumphs and Struggles: Developmental Gap for Biomedical Sciences and Healthcare Systems Innovation in South Africa" for an upcoming book edited by Busani Ngcaweni Sizonqoba: Outliving AIDS in Southern Africa (HSRC/AISA). She teaches political science at Paris-Dauphine University. Contact: charlotte.pelletan[at]gmail.com 